\title{
Retinal and olfactory bulb precursor cells show distinct responses to FGF-2 and laminin
}

\author{
Gaizka Otaegi a , Flora de Pablo a , Carlos Vicario-Abejón ${ }^{\text {a,b }}$, Enrique J. de la Rosa ${ }^{\text {a,* }}$ \\ ${ }^{\text {a }}$ Group of Growth Factors in Vertebrate Development, Cellular and Molecular Physiopathology Department, Centro de Investigaciones Biológicas (CIB), \\ Consejo Superior de Investigaciones Científicas (CSIC), C/Ramiro de Maeztu 9, E-28040 Madrid, Spain \\ ${ }^{\mathrm{b}}$ Instituto Cajal, Consejo Superior de Investigaciones Científicas (CSIC), Av. Doctor Arce 37, E-28006 Madrid, Spain
}

Received 21 June 2006; revised 23 November 2006; accepted 29 November 2006

\begin{abstract}
We analyzed whether the embryonic (E12.5-E14.5) mouse retina possesses genuine neural stem cells and how they respond to defined growth factors and extracellular matrix molecules. Whereas most combinations produced no or limited cell survival and proliferation in culture, FGF-2 plus heparin and laminin stimulated proliferation and the formation of aggregates composed, after two days, of $95.2 \%$ nestin-positive cells. However, cells in these aggregates could only be passaged poorly, lost nestin expression and proliferative capacity, and differentiated into neurons. Under the same conditions, olfactory bulb precursor cells divided efficiently and could be expanded. These data suggest that, in addition to FGF-2 and laminin, embryonic retinal neuroepithelial cells need additional extrinsic and/or intrinsic regulators to maintain cell proliferation and self-renewal.
\end{abstract}

(C) 2006 International Federation for Cell Biology. Published by Elsevier Ltd. All rights reserved.

Keywords: FGF-2; Laminin; Retina; Neural stem/precursor cells; Olfactory bulb

\section{Introduction}

At early stages of embryonic development, neuroepithelial precursor cells of most vertebrate nervous system regions have the potential to differentiate into neurons, astrocytes, and oligodendrocytes and the ability to self-renew, indicating that they are neural stem cells (NSC) (Temple, 2001; VicarioAbejon et al., 2003). NSC have also been isolated from the mammalian adult central nervous system (CNS), including the adult retina (Tropepe et al., 2000; Temple, 2001). Radial glia, such as retinal Müller glia, can also function as neuronal precursor cells (Malatesta et al., 2000; Fischer and Reh, 2001). Early studies reported multipotent precursor cells in the developing neuroretina (Turner and Cepko, 1987; Wetts and Fraser, 1988), although the ability of these precursors to self-renew

\footnotetext{
* Corresponding author. Tel.: +34 $918373112 \times 4375$; fax: +34 915360432.

E-mail address: ejdelarosa@cib.csic.es (E.J. de la Rosa).
}

has not been demonstrated (Akagi et al., 2003; Bhattacharya et al., 2003; James et al., 2003; Ahmad et al., 2004). Most NSC proliferate in culture in response to FGF-2 and EGF in combination with IGF-I and (pro)insulin (Vicario-Abejon et al., 2003). In addition, extracellular matrix (ECM) molecules are also involved in the regulation of precursor cell proliferation in the CNS (Reh and Radke, 1988; Blaess et al., 2004).

Here we studied whether the embryonic mouse retina possesses genuine NSC, and analyzed their responses to defined extracellular factors and ECM molecules. In parallel, we analyzed the responses of well-characterized olfactory bulb stem cells (OBSC; Vicario-Abejon et al., 2003; Yusta-Boyo et al., 2004) to the same factors. In contrast to cells isolated from the olfactory bulb $(\mathrm{OB})$, retinal precursors do not form neurospheres in response to FGF-2. Nonetheless, retinal cells respond to a combination of FGF-2, heparin and laminin by proliferating and forming cell aggregates. These aggregates, however, tend to differentiate in short-term culture and can be expanded poorly. Our results suggest that specific and distinct responses of embryonic retinal neuroepithelial precursors 


\author{
Nomenclature \\ BrdU 5'-bromo-2-deoxyuridine \\ CNTF ciliary neurotrophic factor \\ E embryonic day of development \\ ECM extracellular matrix \\ EGF epidermal growth factor \\ FGF fibroblast growth factor \\ IGF insulin-like growth factor \\ NCS neural stem cells \\ NT neurotrophin \\ OB olfactory bulb \\ OBSC olfactory bulb stem cells \\ PFA paraformaldehyde \\ TGF transforming growth factor
}

to mitogens and ECM molecules are linked to their potential ability for self-renewal in culture.

\section{Materials and methods}

\subsection{Cell culture}

Reagents for tissue culture were purchased from Gibco-Life Technologies (Carlsbad, CA, USA), Sigma (St. Louis, MO, USA) and Worthington (Freehold, NJ, USA). FGF-2, IGF-I, EGF, CNTF, and TGF- $\alpha$ were purchased from PeproTech (Rocky Hill, NJ, USA), NT-3 was from R\&D Systems (Minneapolis, MN, USA); insulin was a kind gift of Eli Lilly (Indianapolis, IN, USA). Heparin and Matrigel were purchased from Serva (Heidelberg, Germany).

Cell cultures were prepared from CD1 mouse embryonic retina on gestational days $12.5,13.5$, and 14.5 (E12.5-E14.5) and from E14.5 olfactory bulb. Animals were cared for in accordance with European Commission guidelines. Whole retinas were dissected out of the eye by separating them from the optical nerve; the pigmented epithelium and the lens were then removed. Cells were obtained by mechanical dissociation of pooled neuroretinas, followed by mild trypsinization. E12.5 whole retinas were first treated with hyaluronidase. After inhibition of enzyme activity with $10 \%$ heat-inactivated FBS, cells were resuspended in Dulbecco's modified Eagle's medium (DMEM)/nutrient mixture F12/insulin, apotransferrin, putrescine, progesterone, sodium selenite ( $\mathrm{N} 2$ supplements), plated on tissue culture dishes and incubated $\left(37^{\circ} \mathrm{C}, 5 \%\right.$ $\mathrm{CO}_{2}$ ). While establishing the culture system, initial cell densities in the range of $35,000-80,000 \mathrm{cells} / \mathrm{cm}^{2}$ were employed without noticeable differences. Thus, 60,000 cells $/ \mathrm{cm}^{2}$ were chosen for further experiments. Defined growth factors and ECM molecules were added daily or every other day.

E14.5 OB cell cultures were prepared by mechanical dissociation and plated on uncoated tissue culture dishes at a density of $35,000 \mathrm{cells} / \mathrm{cm}^{2}$ as described (Vicario-Abejon et al., 2003; Yusta-Boyo et al., 2004). FGF-2 (50 ng/ $\mathrm{ml})$, heparin $(2 \mu \mathrm{g} / \mathrm{ml})$ and laminin $(2 \mu \mathrm{g} / \mathrm{ml})$ were added to expand the proliferative precursor cell population. Under these conditions, OB cells grew as monolayers and were passaged every $3-5$ days by mechanical procedures and plated at 5000 cells $/ \mathrm{cm}^{2}$ for passage.

For cell proliferation assays, cells were pulsed with $5 \mu \mathrm{M} 5^{\prime}$-bromo-2deoxyuridine (BrdU; Boehringer-Mannheim) for $20-22 \mathrm{~h}$ prior to fixation.

\subsection{Immunostaining of cultured cells and sections}

Cultured cells were fixed in $4 \%$ paraformaldehyde (PFA)/0.1 M phosphate buffer, $\mathrm{pH} 7.4$, for $25 \mathrm{~min}$. Cultures incubated with $\mathrm{BrdU}$ were fixed in $4 \%$ PFA/0.1 M borate $\left(\mathrm{Na}_{2} \mathrm{~B}_{4} \mathrm{O}_{7}\right)$ buffer, $\mathrm{pH} 9.5$, for $25 \mathrm{~min}$, treated with $2 \mathrm{~N}$ $\mathrm{HCl}$ for $10 \mathrm{~min}$, and neutralized in $0.1 \mathrm{M} \mathrm{Na}_{2} \mathrm{~B}_{4} \mathrm{O}_{7}$ for $10 \mathrm{~min}$. After treatment with $0.1 \%$ Triton $\mathrm{X}-100 / 10 \%$ normal serum/PBS, cells were incubated $\left(4^{\circ} \mathrm{C}\right.$, overnight) with primary antibodies against nestin (rabbit polyclonal, 1:1000; a kind gift of R.D. McKay, NIH, Bethesda, MD, USA), BrdU (mouse monoclonal, 1:1000-1:2000), and $\beta$-III-tubulin (TuJ1, rabbit polyclonal, 1:20001:4000; Babco, Richmond, CA, USA). Cells were then incubated with the appropriate Alexa fluor 488- or Texas red-conjugated secondary antibodies (1:100; Molecular Probes, Eugene, OR, USA). Controls were performed to confirm antibody specificity. The anti-BrdU monoclonal antibody (G3G4) developed by S.J. Kaufman was obtained from the Developmental Studies Hybridoma Bank maintained by The University of Iowa, Department of Biological Sciences, Iowa City, IA, USA.

For histology, E12.5-E13.5 heads were fixed overnight in 4\% PFA in PBS immersed in $30 \%$ sucrose for $24-48 \mathrm{~h}$, then frozen at $-70{ }^{\circ} \mathrm{C}$ in dry ice. Airdried cryostat coronal sections $(14 \mu \mathrm{m})$ were incubated overnight at $4{ }^{\circ} \mathrm{C}$ or at room temperature with the polyclonal primary antibodies anti-nestin, TuJ1 (1:1500), and anti-phosphohistone H3 (rabbit polyclonal, 1:1000 from Upstate, Lake Placid, NY, USA).

\subsection{Cell counts and statistical analysis}

To determine the number of cells expressing a specific antigen, a total of 10 random fields per chamber were counted using $\times 20$ or $\times 40$ objectives under fluorescence filters. Results are expressed as the number of cells stained for that antigen in 10 fields. Total cell number (stained plus unstained) was counted to calculate the proportion of a specific cell type in the culture. Results are expressed as the mean \pm SEM of data from four cultures of two experiments.

\section{Results}

\subsection{Cell marker expression in the developing retina in vivo}

The expression patterns of nestin (a neuroepithelial cell marker), $\beta$-III-tubulin (TuJ1, a neuronal marker), and phosphohistone $\mathrm{H} 3$ (a mitosis marker) were studied on E12.5E13.5 sections (for references on cell markers, see Ref. Vicario-Abejon et al., 2003). TuJ1-positive cells were located near the optic nerve in E12.5 retinas (Fig. 1A), whereas these cells were distributed throughout E13.5 retinas, with the exception of the edges of the peripheral retina (Fig. 1C, E). Nestin expression was abundant in the E13.5 retina (Fig. 1F) and its distribution pattern partially overlapped that of TuJ1. Phosphohistone H3-positive cells (Fig. 1B, D) were distributed throughout the neuroepithelial zone and were more abundant at E12.5 than at E13.5.

\subsection{Effects of defined molecules on retinal and olfactory bulb precursor cells}

Since nestin-positive cells were abundant in the developing retina (Fig. 1F), cells were isolated and plated in culture to attempt expanding the proliferative precursor cells using growth factor and ECM molecule treatment (Anchan et al., 1991; Klagsbrun and Baird, 1991; Lillien and Cepko, 1992; Hernandez-Sanchez et al., 1995; Das et al., 2000; VicarioAbejon et al., 2003). Retinal cell survival was poor under most conditions (Table 1). Of the factors tested, only FGF-2 (50 ng/ml) plus heparin $(2 \mu \mathrm{g} / \mathrm{ml}$ ) (in polyornithine-coated dishes) promoted formation of small aggregates, although with low efficiency. Since cell responses to growth factors 

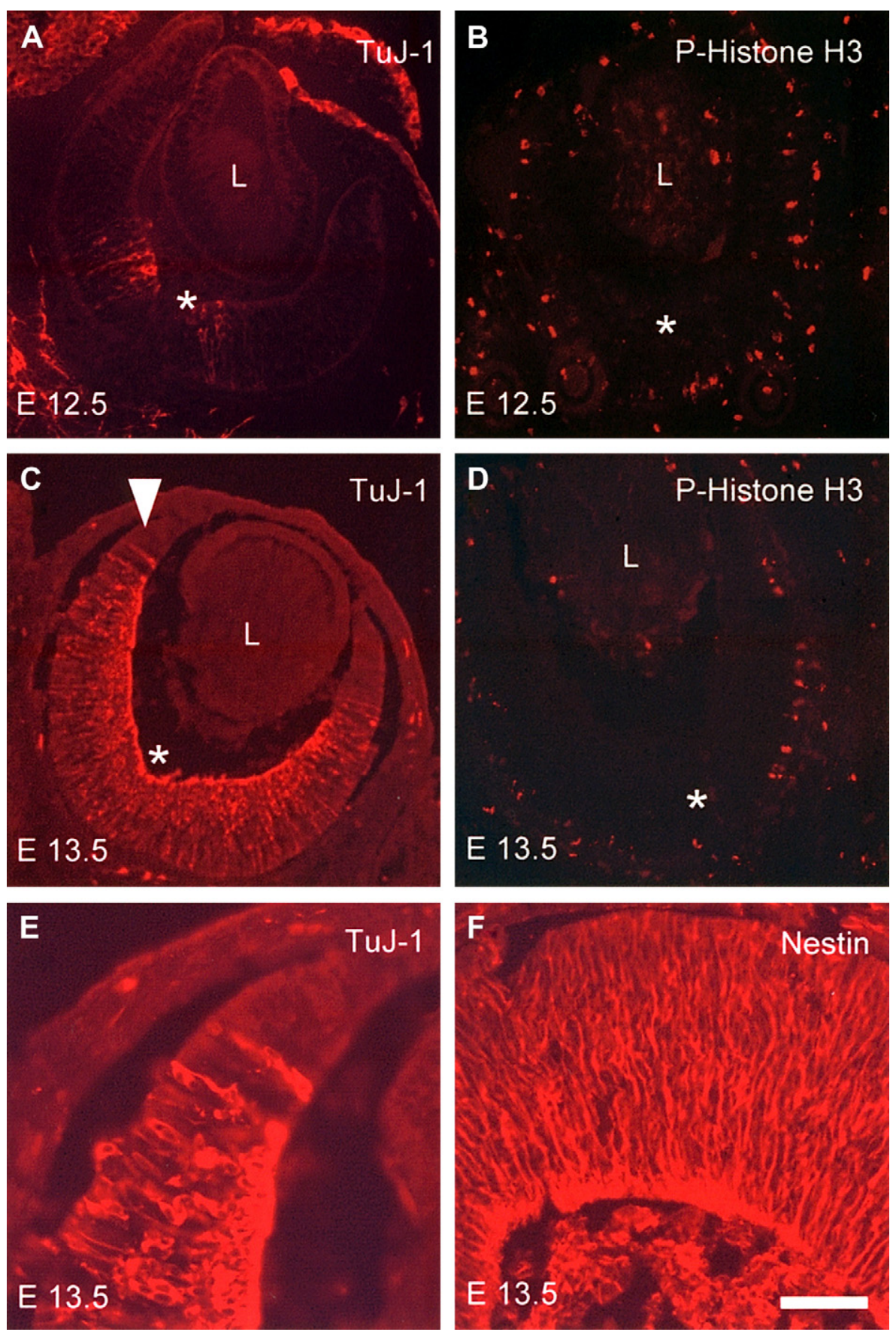

Fig. 1. Cell marker expression in the developing retina in vivo. Coronal sections from E12.5-E13.5 mouse retinas were immunostained with antibodies specific for $\beta$-III-tubulin (TuJ-1; A, C, E), phospho-histone H3 (B, D), and nestin (F). Panel E shows a high magnification image of the area indicated in C with an arrowhead. The asterisk indicates the site in the ganglion cell layer at which the optic nerve leaves the retina. L, lens. Scale bar (shown in $\mathrm{F}$ ), $A-D, 50 \mu \mathrm{m} ; E-F, 20 \mu \mathrm{m}$.

can be modulated by ECM molecules (Colognato et al., 2002), Matrigel $(0.4-1 \%)$, laminin $(1-2 \mu \mathrm{g} / \mathrm{ml})$ and fibronectin $(1-2 \mu \mathrm{g} / \mathrm{ml})$ were added to the cultures in the absence of polyornithine. The combination of FGF-2, heparin and laminin produced a significant increase in the number and size of cell aggregates after three to four days in culture (Table 1; Fig. 2), whereas fibronectin had no significant effects.

Matrigel, which contains high proportion of laminin (Xu et al., 2001), also stimulated aggregate formation in combination with FGF-2, whereas Matrigel alone had no effect. Cell density effect in the range of $35,000-80,000$ cells $/ \mathrm{cm}^{2}$ was minor, with slightly better aspect of the cultures at higher densities. After two days of treatment with FGF-2 plus heparin plus laminin, the proportions of TuJ1-, BrdU-, and nestinpositive cells were $44.9 \%, 45.2 \%$, and $95.2 \%$, respectively (Fig. 3A-F, I). Passage of these aggregates was inefficient, however, and the cells could not be expanded. In addition, the proportions of nestin- and BrdU-positive cells decreased over time, whereas the proportion of TuJ1-positive cells increased (Fig. 3I), even at high cell density, a fact that appears 
Table 1

Effects of defined molecules on retinal precursor cell growth

\begin{tabular}{ll}
\hline Treatment & Growth \\
\hline FGF-2 $20-50 \mathrm{ng} / \mathrm{ml}$ & - \\
FGF-2 $20 \mathrm{ng} / \mathrm{ml}+$ EGF $20 \mathrm{ng} / \mathrm{ml}$ & - \\
FGF-2 $50 \mathrm{ng} / \mathrm{ml}+$ heparin $2 \mu \mathrm{g} / \mathrm{ml}+$ polyornithine & $+/-$ \\
FGF-2 $50 \mathrm{ng} / \mathrm{ml}+$ heparin $2 \mu \mathrm{g} / \mathrm{ml}+$ Matrigel $0.4-1 \%$ & + \\
FGF-2 $50 \mathrm{ng} / \mathrm{ml}+$ heparin $2 \mu \mathrm{g} / \mathrm{ml}+$ fibronectin $1-2 \mu \mathrm{g} / \mathrm{ml}$ & - \\
FGF-2 $50 \mathrm{ng} / \mathrm{ml}+$ heparin $2 \mu \mathrm{g} / \mathrm{ml}+$ laminin $1 \mu \mathrm{g} / \mathrm{ml}$ & ++ \\
FGF-2 $50 \mathrm{ng} / \mathrm{ml}+$ heparin $2 \mu \mathrm{g} / \mathrm{ml}+$ laminin $2 \mu \mathrm{g} / \mathrm{ml}$ & +++ \\
\hline
\end{tabular}

Mouse E13.5 retinal precursor cells were cultured with the indicated growth factors and ECM molecules, and $10 \mu \mathrm{g} / \mathrm{ml}$ insulin (except when IGF-I was tested). Cell survival and formation of cell aggregates in the cultures were evaluated four days after plating (see Fig. 2). As shown, the combination of $50 \mathrm{ng} / \mathrm{ml} \mathrm{FGF-2,} 2 \mu \mathrm{g} / \mathrm{ml}$ heparin and $2 \mu \mathrm{g} / \mathrm{ml}$ laminin produced the best results and was chosen for standard growth conditions for retinal cells. Other factors and combinations tested that did not promote growth were EGF, IGF-I, NT-3, TGF- $\alpha$, CNTF, Matrigel, FGF-2 + NT-3, FGF-2 + TGF- $\alpha$, IGF-I + Matrigel, FGF-2 + polyornithine.

to minimize differentiation of human retinal precursor cells (Ezeonu et al., 2003). These results suggest that the retinal nestin- and BrdU-positive cells do not possess self-renewal capacity under these culture conditions. They also indicate that laminin potentiates the survival and proliferative responses of retinal cells to FGF-2.

Since laminin can also promote neuroepithelial cell differentiation (Wu et al., 2002), and this could be a reason for the increase in the neuronal marker expression in the retinal cultures, OB precursor cells were plated under the same conditions. After two days, the proportions of TuJ1-, BrdU-, and nestin-positive cells were $83.2 \%, 15.7 \%$, and $93.3 \%$, respectively (Fig. 3I). In contrast to retinal cells (Fig. 3A-F), OB precursors grew as monolayers (Fig. 3G, H) and could be passaged efficiently; by day eleven the proportion of BrdU- and nestin-positive cells increased to $98 \%$ and $99.5 \%$, respectively, whereas the proportion of TuJ1-positive cells was $0.06 \%$.

\section{Discussion}

Neuroepithelial precursor cells showing stem cell features have been isolated from the embryonic retinal pigmented epithelium (Coles et al., 2006) and the adult mammalian ciliary margin (Tropepe et al., 2000; Ahmad et al., 2004). In contrast, although multipotent precursors were reported in the developing retina (Turner and Cepko, 1987; Wetts and Fraser, 1988), no precursor cell with self-renewal capacity has been isolated from the embryonic neuroretina (Akagi et al., 2003; Bhattacharya et al., 2003; James et al., 2003; Ahmad et al., 2004). We show that early embryonic mouse retinal precursor cells do not survive significantly or proliferate in culture, in the presence of defined growth factors or growth factorcombinations (FGF-2, EGF, IGF-I, NT-3, CNTF and TGF- $\alpha$ ) in medium containing a high insulin concentration. As cell dissociation may produce loss of critical interactions between growth factors and their receptors and/or between cell membranes and the extracellular matrix, necessary for cell survival


Fig. 2. Growth of early embryonic retinal precursor cells in culture. E13.5 retinal cell suspensions were plated on uncoated tissue culture dishes in the presence of $50 \mathrm{ng} / \mathrm{ml} \mathrm{FGF-2,} 2 \mu \mathrm{g} / \mathrm{ml}$ heparin and $2 \mu \mathrm{g} / \mathrm{ml}$ laminin. A, One day after plating, many cells are seen in the cultures. Only a small percentage of these cells survived and formed small and large aggregates at days 2 (B) and 4 (C). Only minor differences were observed when the cells were plated at initial densities in the range of 35,000-80,000 cells $/ \mathrm{cm}^{2}$. E14.5 cell growth was similar to that of E13.5 cells; E12.5 cells grew poorly under these culture conditions. Scale bar (shown in C), $40 \mu \mathrm{m}$.

and proliferation, we studied the effects of ECM molecules in these processes.

The very weak effect of FGF-2 plus heparin on the formation of retinal cell aggregates is strongly and specifically 

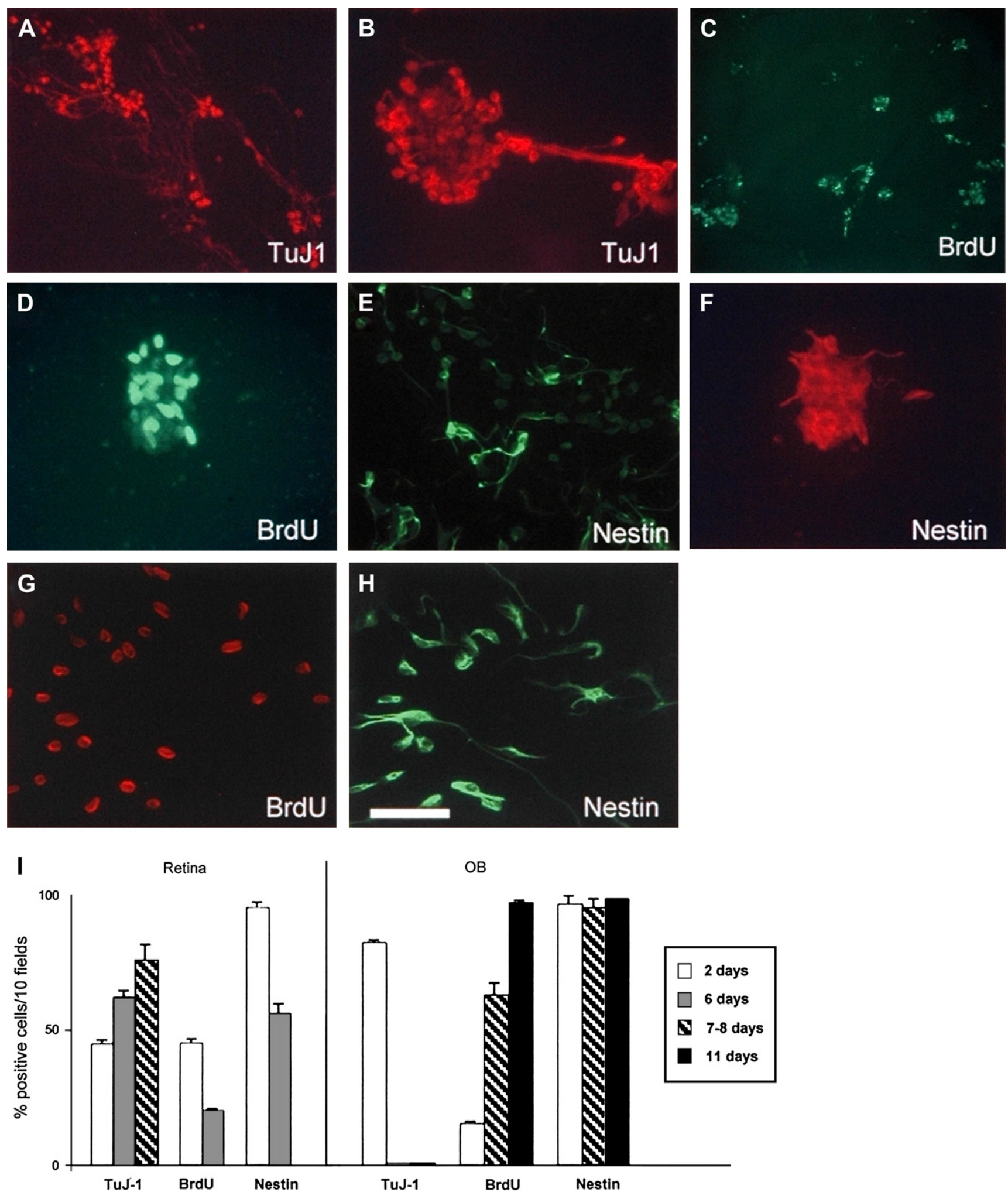

Fig. 3. Cell marker expression in retinal and olfactory bulb precursor cells in culture. Retinal (A-F) and olfactory bulb (G, H) cell suspensions were plated on

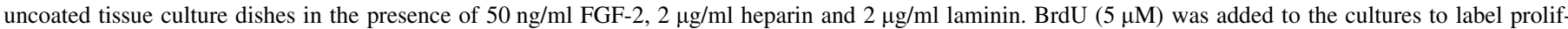
erating cells. Cells were fixed on different days and immunostained with antibodies against $\beta$-III-tubulin (TuJ1; A, B), BrdU (C, D, G), and nestin (E, F, H). The same fields are shown in A, C and E, in B, D and F, and in G and H, respectively. I, the graph shows a time-course of the proportions of TuJ1-, BrdU-, and nestinpositive cells in retinal (left) and olfactory bulb (OB, right) cultures. Note that whereas the percentage of BrdU-positive cells in OB cultures increased with time, retinal cells differentiated and lost nestin expression and proliferative capacity. Results are expressed as the mean \pm SEM of data from four cultures of two experiments. Scale bar (shown in $\mathrm{H}$ ), $A, C, E, G, 50 \mu \mathrm{m} ; B, D, F, H, 20 \mu \mathrm{m}$. 
potentiated by laminin, but this molecule (or Matrigel) alone has no effect. This indicates that laminin is necessary for FGF-2 promotion of retinal precursor cell survival and proliferation as well as aggregation. This cooperative effect between the two proteins, however, does not prevent the loss of nestin expression and induction of neuronal differentiation with time in culture. Although laminin may promote cell differentiation (Wu et al., 2002), which could explain the increase in the number of TuJ1-positive cells in the retinal cultures, OBSC proliferate rapidly in the presence of laminin. These data suggest that, in addition to FGF-2 and laminin, embryonic retinal neuroepithelial cells may need additional signals, including the activation of signaling molecules and transcription factors involved in the stimulation of cell proliferation and selfrenewal, which may occur later in development.

In support of this, late embryonic (E18.5) and early postnatal (P1) retinal precursor cells proliferate (but do not selfrenew) in the presence of EGF (James et al., 2003; Ahmad et al., 2004; Klassen et al., 2004), and adult mouse retinal cells proliferate and self-renew in response to FGF-2, heparin and EGF (Tropepe et al., 2000). Activation of the Delta-Notch pathway may also be important for maintenance of neuroepithelial cells in a precursor state. Rat retinal stem cells isolated from E14 and E18 embryos as well as from the adult ciliary margin express Notch, whereas expression of its ligand Delta increases from background levels at E14 to significant levels in the adult. In addition, signaling through the Wnt-Frizzled pathway and activation of the c-kit receptor tyrosine kinase by its ligand stem cell factor, promotes neurosphere formation by adult ciliary margin stem cells (Ahmad et al., 2004).

Neuroepithelial precursor cells from many CNS regions tend to differentiate in culture (Reh and Kljavin, 1989; VicarioAbejon et al., 1995). To our knowledge, with the exception of embryonic retinal cells, the precursors can be stimulated to proliferate and self-renew in response to FGF-2, EGF and members of the insulin family of growth factors (VicarioAbejon et al., 2003). In contrast, the data presented here and results from other groups (Ahmad et al., 2004) suggest that proliferation (and possibly the ability to self-renew) of retinal precursor cells is finely regulated during development and adult life, by activation of a number of signaling components, including activation of the FGF-2 receptor tyrosine kinase signaling pathway by laminin. Understanding the differences between neuroepithelial cells from different regions might facilitate their manipulation in vitro, and eventually shed light on their behavior in vivo, with the long-term aim of using them for treating CNS disorders.

\section{Acknowledgements}

This work was funded by grants BMC2003-07751 and BFU2004-02352 from the MEC (Spain) to EjdlR and FdP respectively, and by grants SAF2004-05798 from the MEC and NE03/72-02 from Fundación La Caixa to CVA. GO is a doctoral Fellow from the MEC.

\section{References}

Ahmad I, Das AV, James J, Bhattacharya S, Zhao X. Neural stem cells in the mammalian eye: types and regulation. Semin Cell Dev Biol 2004;15:53-62.

Akagi T, Haruta M, Akita J, Nishida A, Honda Y, Takahashi M. Different characteristics of rat retinal progenitor cells from different culture periods. Neurosci Lett 2003;341:213-6.

Anchan RM, Reh TA, Angello J, Balliet A, Walker M. EGF and TGF-alpha stimulate retinal neuroepithelial cell proliferation in vitro. Neuron 1991;6: 923-36.

Bhattacharya S, Jackson JD, Das AV, Thoreson WB, Kuszynski C, James J, et al. Direct identification and enrichment of retinal stem cells progenitors by Hoechst dye efflux assay. Invest Ophthalmol Vis Sci 2003;44:2764-73.

Blaess S, Graus-Porta D, Belvindrah R, Radakovits R, Pons S, LittlewoodEvans A, et al. Beta1-integrins are critical for cerebellar granule cell precursor proliferation. J Neurosci 2004;24:3402-12.

Coles BL, Horsford DJ, McInnes RR, van der Kooy D. Loss of retinal progenitor cells leads to increase in the retinal stem cell population in vivo. Eur J Neurosci 2006;23:75-82.

Colognato H, Baron W, Avellana-Adalid V, Relvas JB, Baron-Van Evercooren A, Georges-Labouesse E, et al. CNS integrins switch growth factor signalling to promote target-dependent survival. Nat Cell Biol 2002; 4:833-41.

Das I, Sparrow JR, Lin MI, Shih E, Mikawa T, Hempstead BL. Trk C signaling is required for retinal progenitor cell proliferation. J Neurosci 2000;20: 2887-95.

Ezeonu I, Wang M, Kumar R, Dutt K. Density-dependent differentiation in non-transformed human retinal progenitor cells in response to basic fibroblast growth factor and transforming growth factor $\alpha$. DNA Cell Biol 2003; 22:607-19.

Fischer AJ, Reh TA. Muller glia are a potential source of neural regeneration in the postnatal chicken retina. Nat Neurosci 2001;4:247-52.

Hernandez-Sanchez C, Lopez-Carranza A, Alarcon C, de La Rosa EJ, de Pablo F. Autocrine/paracrine role of insulin-related growth factors in neurogenesis: local expression and effects on cell proliferation and differentiation in retina. Proc Natl Acad Sci U S A 1995;92:9834-8.

James J, Das AV, Bhattacharya S, Chacko DM, Zhao X, Ahmad I. In vitro generation of early-born neurons from late retinal progenitors. J Neurosci 2003; 23:8193-203.

Klagsbrun M, Baird A. A dual receptor system is required for basic fibroblast growth factor activity. Cell 1991;67:229-31.

Klassen HJ, Ng TF, Kurimoto Y, Kirov I, Shatos M, Coffey P, et al. Multipotent retinal progenitor express developmental markers, differentiate into retinal neurons, and preserve light-mediated behavior. IOVS 2004;45: 4167-73.

Lillien L, Cepko C. Control of proliferation in the retina: temporal changes in responsiveness to FGF and TGF alpha. Development 1992;115: 253-66.

Malatesta P, Hartfuss E, Gotz M. Isolation of radial glial cells by fluorescentactivated cell sorting reveals a neuronal lineage. Development 2000;127: 5253-63.

Reh TA, Kljavin IJ. Age of differentiation determines rat retinal germinal cell phenotype: induction of differentiation by dissociation. J Neurosci 1989;9: 4179-89.

Reh TA, Radke K. A role for the extracellular matrix in retinal neurogenesis in vitro. Dev Biol 1988;129:283-93.

Temple S. The development of neural stem cells. Nature 2001;414:112-7.

Tropepe V, Coles BL, Chiasson BJ, Horsford DJ, Elia AJ, McInnes RR, et al. Retinal stem cells in the adult mammalian eye. Science 2000;287: 2032-6.

Turner DL, Cepko CL. A common progenitor for neurons and glia persists in rat retina late in development. Nature 1987;328:131-6.

Vicario-Abejon C, Johe KK, Hazel TG, Collazo D, McKay RD. Functions of basic fibroblast growth factor and neurotrophins in the differentiation of hippocampal neurons. Neuron 1995;15:105-14.

Vicario-Abejon C, Yusta-Boyo MJ, Fernandez-Moreno C, de Pablo F. Locally born olfactory bulb stem cells proliferate in response to insulin-related 
factors and require endogenous insulin-like growth factor-I for differentiation into neurons and glia. J Neurosci 2003;23:895-906.

Wetts R, Fraser SE. Multipotent precursors can give rise to all major cell types of the frog retina. Science 1988;239:1142-5.

Wu P, Tarasenko YI, Gu Y, Huang LY, Coggeshall RE, Yu Y. Region-specific generation of cholinergic neurons from fetal human neural stem cells grafted in adult rat. Nat Neurosci 2002;5:1271-8.
Xu C, Inokuma MS, Denham J, Golds K, Kundu P, Gold JD, et al. Feeder-free growth of undifferentiated human embryonic stem cells. Nat Biotechnol 2001;19:971-4.

Yusta-Boyo MJ, Gonzalez MA, Pavon N, Martin AB, De La Fuente R, Garcia-Castro J, et al. Absence of hematopoiesis from transplanted olfactory bulb neural stem cells. Eur J Neurosci 2004;19: 505-12. 